\title{
Education Financing Management in an Effort to Improve the Quality of Learning in Madrasah Aliyah in Bandung District: Studies at MA Al Mua'wanah Majalaya and MA Al Jawahir Soreang
}

\author{
Inal Kahfi, Achmad Sanusi, Hanafiah, Deti Rostini \\ Universitas Islam Nusantara, Bandung, Indonesia \\ Email: Inalkahfi85@gmail.com, achmadsanusi@uninus.ac.id, hanafiah@uninus.ac.id, \\ detirostini@uninus.ac.id
}

\begin{abstract}
ARTICLE INFO
Received

08 September 2021

Revision

13 September 2021

Approved

22 September 2021

Keywords:

Education Financing

Management;

Learning Quality

\section{ABSTRACT}

Implementing education in madrasas requires financial management because it has powerful potential and is inseparable from education management. Grand Theory research uses the theory of George R. Terry, into some of the essential functions of management, into Planning (Planning), Organizing (Organizing), Actuating (Implementation), and Controlling (Supervision). The results showed that the management of education financing to improve the quality of learning in Madrasah Aliyah was still not optimal. It is proven that the quality of learning has met the standard of the learning process and seen from the teaching staff's readiness to prepare the learning process by the format of the national education quality standard. However, let's look closely at the occurrence of learning interactions between educators and students. Some educators need to increase their ability to stimulate stimulus responses from students in encouraging motivation, interest, and serious attention in developing and mastering learning materials.
\end{abstract}

\section{INTRODUCTION}

Schools are the main key in forming quality human beings, and it is all supported by good educational processes and facilities, therefore, financing is also one of the factors that can produce quality and quality graduates (Febriyanti, 2020). Where quality includes input, process, and output (SITI, 2021).

Educational institutions from all levels of education, from elementary to tertiary levels, require operational activities to mobilize all their resources. (Saway \& Hidayat, 2019) Because the education process will not be adequate without the availability of facilities and infrastructure resources (Barnawi \& Arifin, 2012) Therefore, the focus of education financing management lies in how the existing funding sources can be managed appropriately. professional so that the needs of education can be met (Muqit \& Listiana, 2021).

The purpose of education is to develop the potential of students to become human beings who believe and fear God Almighty, have a noble character, are healthy, knowledgeable, capable, creative, independent, and become democratic and responsible citizens. Educational goals will be achieved effectively and efficiently if schools are supported by two factors, namely internal factors related to school management and external factors, namely community factors which are consumers who also determine the 
success of education. Therefore, the supervision of the implementation of a program must be by the requirements that have been previously planned (Sudrajat, 2019)

Data from a survey on the Human Development Index (HDI) by the United Nations Development Program or UNDP (Kahfi, 2019) stated that Indonesia was ranked 113 out of 177 countries in the world. Based on the results of the UNDP survey, the low human resources in Indonesia result from the low quality of learning in various types and levels of education. 20 of 2003, which leads to improving the quality and relevance of education.

The existence of Madrasah Aliyah is recognized as part of the national education system that is not distinguished from similar general education institutions as regulated in the form of recognition of Religious Education as one type of education in the national education system embodied in Law Number 20 of 2003 concerning the National Education System as described in Article 15 Law Number 20 of 2003 concerning the National Education System: "Types of education include general, vocational, academic, professional, vocational, religious, and special education."

As a follow-up to the mandate of the Law above regarding the financing of education, it has been regulated in the 1945 Constitution of the Republic of Indonesia (Amendment IV), which states that every citizen has the right to education; every citizen is obliged to attend primary education, and the Government is obliged to pay for it; the Government seeks and organizes a national education system, which increases faith and purity as well as a noble character in the context of the intellectual life of the nation, which Law regulates; the state prioritizes the education budget at least twenty percent of the State Revenue and Expenditure Budget (APBN) as well as from the Regional Revenue and Expenditure Budget (APBD) to meet the needs of the implementation of national education; the Government advances science and technology by upholding religious values and national unity for the advancement of civilization and the welfare of humanity.
(Indonesia, 2003) concerning the National Education System, further stipulates several articles that explain education funding. In Article 11 Paragraph 2, the Government and Regional Governments are obliged to guarantee the availability of funds to implement education for every citizen aged seven to fifteen years.

Furthermore, Article 12, Paragraph (1) states that every student in each academic unit is entitled to a scholarship for outstanding achievers whose parents cannot afford to pay for their education and education costs for those whose parents are unable to pay for their education. In addition, it is also stated that every student is obliged to share the costs of providing education, except for students who are exempt from this obligation by applicable laws and regulations.

Government Regulation No.19/2005 concerning National Education Standards In Chapter IX: Financing Standards, Article 62, it is stated that: 1) Education financing consists of investment costs, operating costs, and personal costs. 30 2) The investment cost of the education unit, as referred to in Paragraph (1), includes the cost of providing facilities and infrastructure, developing human resources, and permanent working capital. 3) Personal costs, as referred to in Paragraph (1), include educational costs that students must incur to participate in the learning process regularly and continuously. 4) The operational costs of the education unit as referred to in Paragraph (1) include a) Salaries of educators and education personnel and all allowances attached to salaries. b) Consumable educational materials or equipment, and c) Indirect educational operating costs in the form of power, water, telecommunications services, maintenance of facilities and infrastructure, overtime pay, transportation, consumption, taxes, insurance, and so on. 5) Standard operating costs of education units are stipulated by a Ministerial Regulation based on the proposal of the BSNP

Government Regulation of the Republic of Indonesia, Number 48 of 2008 concerning Education Funding 1,) Responsibility for education funding: Article 2 paragraph (1) states that education funding is a shared responsibility between the Government, local governments, and the community. 
The community as referred to in Paragraph (1) includes a) Providers or academic units established by the community; b) Students, parents, or guardians of students; and c) Other parties other than those referred to in letters $a$ and $b$ that have attention and roles in the field of education.

Education funding sources are determined based on the principles of equity, adequacy, and sustainability. b) The principle of justice as referred to in paragraph (1) means that the amount of funding for education by the Government, regional Government, and the community is adjusted to their respective abilities. c) The principle of adequacy as referred to in paragraph (1) means that education funding is sufficient to finance the implementation of education that meets the National Education Standards. d) The principle of sustainability, as referred to in Paragraph (1), means that education funding can be used on an ongoing basis to provide educational services that meet the National Education Standards.

Education funding comes from the Government, local governments, and the community. b) Regional government education funds as referred to in Paragraph (1) can be sourced from (1) Government Budget; (2) Local government budget; (3) Non-binding assistance from foreign parties; and (4) other legitimate sources. (5) Funds for the education provider or academic unit established by the community can be sourced from the Founder of the organizer or education unit established by the community; assistance from the community, outside of students or their parents/guardians; Government Assistance; Local government assistance; Non-binding foreign assistance; The results of the business of the organizer or academic unit; and other legitimate sources.

Principles of Management Article 58

Principles in managing education funds by the Government, regional governments, providers, and academic units established by the community consist of: a) General principles; b) Specific principles.

Education budget planning by the Government must be in line with: a) Longterm development plans; b) Medium-term development plan; c) Government work plan; and the national education strategic plan.
Realization of receipts and expenditures of Government education funds is recorded and reported by accounting standards applicable to Government agencies. Completing receipts and expenses of education funds for education units is recorded and written by non-profit financial accounting standards applicable to education units. 8) Supervision, Examination, and Accountability. a) Supervision of the receipt and use of education unit funds organized by the Government is carried out by laws and regulations. b) Examination of acceptance and use and for supervision as referred to in Paragraph (1) is carried out by the provisions of the legislation. c) Article 79 Education funds in education units organized by the Government and regional governments are accounted for by the provisions of laws and regulations.

The laws and several government regulations above serve as a reference in implementing financing management in each education unit so that any financing carried out can run effectively and optimally to develop the quality of education.

As a local community organization with a strong influence on the community, Madrasah Aliyah has developed through its innovations from an educational institution to a community empowerment institution which has been proven to have contributed a lot to improving the community's welfare through various activities it does. Thus, all stakeholders need to understand the position of Madrasah Aliyah not only as a religious institution and educational institution (religious education) but also as a social institution. This is the determining factor where even though it is hundreds of years old, Madrasah Aliyah until now still exists as an integral part of the nation's strength, even stronger.

Madrasah Aliyah, which was initially considered an alternative educational institution, has now experienced a caste increase to become a solutive and substantive educational institution. Currently, Madrasah Aliyah is regarded as the only educational institution that still exists to shape the character and personality of this nation's next generation. Madrasah Aliyah must be able to improve the quality of its education.

According to (Sugandi 2019), Madrasah is believed to be an effort to perfect the 
pesantren education system towards modern Islamic education. In the history of the development of madrasas in Indonesia, initially, madrasas were very concerned with religious learning rather than general teaching. The madrasa curriculum consists of $70 \%$ Islamic spiritual lessons and 30\% available lessons. As a result, madrasa graduates find it challenging to continue to public education institutions. Along with its development, it was finally determined that public madrasas would apply $100 \%$ of the general education curriculum plus Islamic religious lessons. Meanwhile, madrasas that specifically teach Islamic education are accommodated as diniyah madrasas.

In the latest curriculum - the 2013 curriculum, madrasah tsanawiyah only applies $25 \%$ of Islamic religious lessons, and the remaining $75 \%$ are general lessons. For example, at the Madrasah Tsanawiyah, these Islamic spiritual lessons include the subjects of Quran Hadith (2 JMP), Fiqh (2 JMP), Akidah Akhlak (2 JMP), History of Islamic Culture (2 JMP), and Arabic Language (3 JMP). The percentage of Islamic religious lessons is much different from Islamic education in Islamic boarding schools.

Amid Madrasa, modernization efforts are also developing efforts to legalize pesantren education as part of the national education system. Regulations govern Madrasah diniyah schooling, the curriculum of which is $100 \%$ Islamic. From that moment on, teaching in Islamic boarding schools was directed to become Madrasah diniyah to receive funding from the Government. In addition, mosque-based institutions and foundations have started to establish madrasah diniyah.

On the other hand, the emergence of madrasah diniyah seems to open a dichotomy with general madrasas (ibtidaiyah, tsanawiyah, and aliyah). And this dichotomy is increasingly evident in many state madrasah. The orientation of public madrasah management is centered on efforts to catch up with madrasas and public schools, such as orientation on the achievement of targets for the National Examination (UN) scores and participation in competitions. Likewise, Islamic religious lessons are taught using the methods used to teach general lessons in learning methods. The orientation to not be inferior to public schools has weakened the characteristics of madrasas so that the attributes of pesantren education do not appear.

Restoring madrasas characterized by pesantren education is not easy, but it can be done. Currently, the awareness of the Islamic community for religious education is starting to increase, it is identified from the increasing number of students studying at madrasas. Likewise, Islamic-based public education institutions began to thrive and develop rapidly.

It is time for madrasa institutions to create a madrasa environment with Islamic culture, learning that emphasizes religious knowledge for students - not just memorization, and graduation targets with mastery of reading and memorizing the Koran to mastering general lessons.

The quality of learning in Madrasah Aliyah will be achieved if the standards of the educational process can be met and pursued correctly as a whole.

Process standards are national education standards related to implementing learning in an academic unit to achieve graduate competency standards. The scope of the standard process for primary and secondary education units, according to Permendiknas RI number 41 of 2007, includes planning the learning process, implementing the learning process, assessing learning outcomes, and supervising the learning process. In terms of function, education is called quality if students experience a real and meaningful learning process, supported by an effective teaching and learning process. The learning process in academic units is held interactively, inspiring, fun, challenging, motivating students to participate actively, and providing sufficient space for the initiative, creativity, and independence by students' talents, interests, and physical and psychological development. In addition, in the learning process, educators provide examples.

One of the national education standards that must be pursued is the quality standard. Quality standards include planning the quality of learning, implementing the quality of learning, assessing learning outcomes, and controlling the quality of learning to implement effective and efficient learning quality. 
The quality of learning is the quality of interactive activities between teacherstudents and reciprocal communication in educational situations to achieve learning objectives (Agatha, 2019). In the quality of education, teachers and students are two components that cannot be separated. Mutually supportive interactions must be established between the two components to achieve student learning outcomes optimally.

Three factors play a role in the management system of Madrasah Aliyah, namely, management as a factor of effort, the organization as a factor of facilities, and administration as a factor of the initiative. These three factors provide direction and integration in formulating, controlling, administering, supervising, and assessing the implementation of policies to organize educational activities by the objectives of each Madrasah.

Madrasah Aliyah, as the oldest Islamic educational institution in Indonesia, has experienced a lot of shifts in orientation from the salaf format to modern so that it impacts the ability of the students to master Islamic knowledge from classical sources. So, to return the position to its original role, namely to give birth to cadres of ulama, of course, by making improvements both on the internal and external sides of the institution in a systematic and organized manner so that the output will have a totality advantage that is not only superior in the study of classical books alone. But also excels in general knowledge, management, and administration as a counterweight to the progress of the times so that more optimal control of Madrasah Aliyah is needed.

In the management of Madrasah Aliyah, education financing management is needed. Madrasah Aliyah education financing management is one of the substances in educational institutions that will also determine the smooth running of Madrasah activities.

The financing standard is a standard that regulates the components and the number of operating costs of an academic unit that is valid in one year. Educational financing standards consist of investment costs, operational costs, and personal costs.

Investment costs include the cost of providing infrastructure, human resource development, and fixed working capital.
Operational costs include educational costs that students must incur to follow the learning process regularly and continuously. Education unit operational costs include salaries of educators and education personnel as well as allowances attached to salaries, consumable educational materials or equipment, and direct educational operating expenses in the form of power, water, telecommunications services, maintenance of facilities and infrastructure, overtime pay, transportation, consumption, taxes, insurance, and so on.

In the implementation of education, finance and financing is a powerful potential and are an inseparable part of the study of education management.

The financial and financing components are consumptive productive components that determine to teach and to learn quality activities in schools and other details. In other words, every action carried out by the school requires a fee, both consciously and unconsciously.

This financial and financing component needs to be managed and use existing funds optimally to support educational goals. This is important, especially in the context of SBM, which authorizes schools to seek and utilize various sources of funds according to each school. In general, the world of education is constantly faced with limited funds.

This is in line with (Shunhaji, Abd Muid, \& Desniati, 2020), explaining that financing management factors strongly influence Madrasah Aliyah as an educational institution. In carrying out the quality of Madrasah Aliyah financing management using the system. In this case, the system in question is a technology system, which turns out to be a bit difficult in terms of system migration. In the past, Madrasah Aliyah used a manual system. With the development of technology, there were demands of the times towards a better design and supporting the sustainability of management quality.

Education financing management activities include obtaining and determining funding sources, utilization of funds, reporting, inspection, and accountability.

Based on data from the Ministry of Religion of Bandung Regency (2019), the number of Madrasah Aliyah in Bandung Regency is 98 Madrasah Aliyah spread across various sub-districts. Only $50 \%$ of Madrasah 
Aliyah in Bandung Regency have implemented education financing management. One of the areas in Soreang District is only $10 \%$ that have implemented education financing management and in Majalaya District only $10 \%$ so that the quality of learning is not good.

Based on the results of an interview with the Head of the Madrasah Section of the Ministry of Religion, Bandung Regency, on June 15, 2020, it was explained that Madrasah Aliyah in Bandung Regency had not all implemented education financing management. Both Madrasah Aliyah has implemented education financing management. However, it is still not optimal, so that the quality of learning in Madrasas is not optimal.

Managing finances is not an easy problem amid curriculum changes that continue to change every time that requires the need for supporting facilities and infrastructure, as well as the needs of every teacher and staff of MA Al Muawanah Majalaya and MA Al Jawahir Soreang, which is constantly changing with existing policies so that in the period 2010-2011 experienced a lack of funding which made it challenging to develop educational programs.

In connection with this, the authors chose the title "Education Financing Management to Improve the Quality of Learning at Madrasah Aliyah in Bandung Regency" (Studies at MA Al Mua'wah Majalaya and MA Al Jawahir Soreang).

\section{METHOD}

This research on education financing management in improving the quality of learning at Madrasah Aliyah in Bandung Regency uses a qualitative research approach.

The reason for choosing the qualitative method is that the purpose of this study is to explain the description of education financing management to improve the quality of learning. This is undoubtedly less meaningful when approached with quantitative research, which emphasizes proving hypotheses by describing phenomena through numbers and statistics.

\section{RESULTS AND DISCUSSION}
A. Research Findings at Mua'wanah Majalaya

\section{Education Financing Planning}

The budgeting process at MA Al Mua'wanah Majalaya begins with (1) madrasa plenary meetings, (2) knowing the madrasa admission plan, (3) identifying the madrasah expenditure plan, (4) preparing the RAPBM, (5) revising the RAPBM, (6) to the stage of ratification of the RAPBM.

Before the new school year began, MA Al Mua'wanah Majalaya held a madrasa plenary meeting related to the discussion of the RAPBM. In the 2017/2018 academic year, an entire session was born on June 20, 2017. This meeting was attended by the head of the Madrasa, ten teacher councils, the madrasa treasurer, the chairman of the Foundation, two representatives of the management of the MA Al Mua'wanah Majalaya Foundation, and 58 parents of MA MA Al Mua' with Majalaya.

This plenary meeting, held annually, discusses the financing of madrasas, including discussions regarding what fees will be charged to the guardians of students, determining the nominal amount, and discussions related to the preparation of the RAPBM. The plenary meeting also discussed plans for school development to improve the quality of education for the following year.

Before preparing the RAPBM, the school must identify what the sources of school revenue are. This process is essential to determine whether the income is sufficient to finance education or schools need to find other sources of income.

The sources of income that have been identified are then calculated and the amount estimated. The source of revenue obtained by MA Al Mua'wanah Majalaya comes from BOS funds and parental contributions.

In determining the MA Al Mua'wanah expenditure plan, it refers to the vision, mission of the Madrasa. By referring to the invention, the mission of the Madrasa will make the expenditure of the Madrasah effective because it is by what is the goal of the Madrasa. 
Madrasah expenditures consist of school program expenditures, nonschool program expenditures, and other expenditures. After identifying the madrasa revenues and spending, the madrasah principal and madrasa treasurer formulate the nominal amount for each expenditure post into the RAPBM, compiled according to the draft form prepared agreed.

The draft RAPBM that has been prepared will later be proposed to the Foundation for approval. After the draft RAPBM is submitted to the Foundation, the next step is to discuss the RAPBM between the head of the Madrasa and the chairman of the Al Mu'awanah Majalaya Foundation. The revised RAPBM will later be ratified or approved for implementation. The ratification of the RAPBM is carried out by the principal and the head of the Foundation, namely by signing the RAPBM, so that the Madrasa can immediately implement the RAPBM. The preparation of the RAPBM (Madrasah Revenue and Expenditure Budget Plan) is an activity that must be carried out by an educational institution, in this case, madrasas. Therefore the RAPBM needs to be planned.

The budgeting process at MA Al Mua'wanah Majalaya started by holding (1) a plenary meeting, (2) identifying the madrasa admission plan, (3) identifying the madrasah expenditure plan, (4) preparing the RAPBM, (5) revising the RAPBM, (6) to the stage of ratification of the RAPBM.

Based on the opinion expressed by (Fattah 2004), there are several differences between Fattah's statement and the implementation of budgeting or budgeting at MA Al Mu'awanah Majalaya.

In (Fattah, 2004) the first stage in budgeting is to identify activities for one fiscal year. The implementation at MA Al Mua'wanah Majalaya is the first stage, namely holding a plenary meeting, which will be carried out by MA Al Mua'wanah Majalaya for one fiscal year, meaning that MA Al Mua'wanah Majalaya also identifies activities for one budgetary year in plenary meetings.

Another difference between Fattah's opinion and the implementation of financial planning at MA Al Mua'wanah Majalaya is identifying expenses during one fiscal year.

In addition to identifying madrasah admissions, MA Al Mua'wanah Majalaya also identified madrasah expenditures so that madrasas could prioritize expenses that became madrasah priorities in improving the quality of education.

Identification of expenditures is also needed to make it easier for madrasas or schools to carry out financial budgeting effectively and efficiently.

Every transaction related to school finances, both receipt and expenditure transactions, is always kept in the books to avoid typos or misunderstandings in the future because the treasurer forgets to record the transactions that have occurred.

The forms of bookkeeping or financial records used at MA Al Mua'wanah Majalaya include general cash books, cash subsidiary books, bank subsidiary books, salary receipt books, financial statements, invoices, and savings books.

The general cash book format used by MA Al Mua'wanah Majalaya contains the date, no. Code, no. evidence, description, receipts, disbursements, and balances. The function of the general cash book is to record daily receipts and disbursements; besides that, it also contains ratios at the end of each month.

This general cash book is recorded and reported every month to the head of the Madrasa. Through this available cash book, the head of the Madrasa can find out how much the Madrasa has received and spent.

The cash assistant book at MA Al Mua'wanah Majalaya is intended to record receipts and expenses. It is the same as the general cash book, but this cash subsidiary ledger functions 
more to assist recording before being transferred to the public ledger. The cash ledger contains a debit column for receipts and a credit column for expenses. This cash subsidiary book is usually used when Madrasa has not received the BOS funds.

\section{Implementation of Education} Financing

The implementation of education financing at MA Al Mua'wanah Majalaya has adhered to the principle of adequate education financing, meaning that the allocation of existing funds is used by the vision and mission of the Madrasa. To continuously improve the quality of education according to the vision and mission of the current funds, most of them are allocated for school programs. At the same time, using the efficient principle means that MA Al Mua'wanah Majalaya, in improving the quality of education, can emphasize costs, especially fees charged to parents.

The salary receipt book at MA Al Mu'awanah Majalaya is made to record the salaries of teachers and employees who have been paid. The wages of teachers and employees are given once a month. Each teacher and employee receives compensation for the workload imposed on the teacher and employee.

Teachers and employees must provide duplicate signatures as proof that the teacher or employee has received a salary every month.

The bank sub-book at MA Mua'wanah Majalaya was created to facilitate recording transactions related to bank services. Bank account bookkeeping is essential because, through Madrasah's account, BOS funds can be disbursed. This bank subsidiary ledger is prepared once a month as a report.

The format of the bank subsidiary ledger used is a date, no. Code, no. evidence, descriptions, debits for receipts, credits for expenses, and balances. Financial reports at MA Al Mua'wanah Majalaya are made every month. This financial report is made in the format of the number, date, and name of the transaction, debit, credit, and balance. This financial report will be reported every month to the head of the Madrasa to make it easier for the head of the Madrasa to control the Madrasa's finances regarding the receipts and expenses of the Madrasa every month.

Another document used in financial records at MA Al Mua'wanah Majalaya is an invoice. What is meant by an invoice in financial records at MA Al Mua'wanah here can be in the form of a cash note, receipt, or proof of payment and other valid proof of purchase as proof of the transaction?

Bookkeeping in the financial recording process which MA Al Mua'wanah Majalaya also uses is a savings book.

The savings book here is a ledger that contains records of student savings or student money stored at school. Each student has their account number in the passbook under the school treasurer. Recording education finances is an important step that must be taken to implement (Fattah, 2004)education financial transparency.

Some of the financial records used by MA Al Mua'awanh in the financial recording process include general cash books, cash subsidiary books, invoices, bank subsidiary books, salary receipts books, financial statements, and savings books.

The bookkeeping carried out by MA Al Mua'wanah uses various books with different accounting functions in each book. Still, suppose it is associated with (Fattah 2004). In that case, some books are not carried out by MA Al Mua'wanah, such as postal books, journals, general ledger, tuition payment cash book, and accounts receivable cash book and trial balance. And there are also some books of accounts carried out by MA Al Mua'wanah but not in Fattah's opinion, such as cash subsidiary books, bank subsidiary books, salary receipt books, financial statements, and savings books.

MA Al Mu'awanah did not use the postal book because the postal book 
was deemed ineffective. After all, the treasurer was required to record in two books, namely the postal book and the general cash book. Journals are not used in financial records because daily records are recorded in the public ledger.

The cash book for paying school fees is not used because the Madrasa does not charge tuition fees to students so that the cash book for payment is not needed. Madrasas do not use the trial balance because financial control is carried out by the head of the Madrasa every month using financial reports prepared by the treasurer. The cash subsidiary ledger is used in financial records at MA Al Mua'wanah to record transactions before being transferred to the general cash book. This cash subsidiary book is more used when Madrasa has not received BOS funds.

The use of the salary receipt book at MA Al Mua'wanah to record the amount of salary that must be paid to teachers and employees every month, the salary receipt book here is also legal proof of payment of teacher and employee salaries because every teacher and employee who has received compensation is required to sign the acceptance book this salary.

The BOS funds received by MA Al Mua'wanah are disbursed through a bank account. Therefore, a bank subsidiary book is needed to determine the amount of madrasa money stored in the bank.

Financial reports are needed to make it easier for the head of the Madrasa to control the finances of the Madrasa every month. The use of savings books by MA Al Mu'awanah to find out how much money students save at school.

Each accounting book in financial records has its uses and functions. So that in the process of financial recording, the accounting books used should adjust to the needs of each school. Bookkeeping by the conditions and circumstances of the school will later make the financial recording process effective and efficient.
Through these financial records, madrasas can carry out and maintain financial accountability of madrasas, meaning that the money that has been spent can be accounted for by the parties concerned, such as parents, foundations, and the Government.

\section{Supervision/Evaluation}

\section{Education Financing}

Financial supervision is one of the stages in managing education financing at MA Al Mua'awanah, which controls the planning and implementation of madrasa finances.

Financial supervision needs to be carried out as a form of financial transparency of the Madrasa; through this financial supervision, interested parties such as the Government and foundations can find out the financial condition of MA Al Mua'wanah.

This financial supervision is carried out to determine the economic truth by examining the implementation and financial planning. Supervisors help improve CPW well-being when they offer assistance with complex tasks, help them develop clinical judgment, deliver regular and high-quality clinical supervision, and offer them emotional support during challenging moments (Lamothe, Geoffrion, Couvrette, \& Guay, 2021).

Financial supervision at MA Al Mua'wanah is carried out internally and externally. Internal financial management is carried out by the principal once a month by examining the financial statements that the treasurer has prepared. At the same time, external financial supervision is carried out by the chairman of the Foundation and the Government.

Supervision by the head of the Foundation is carried out once a year. In contrast, financial management by the Government, in this case, is the ministry of religion is carried out once every quarter.

Financial supervision aims to ensure that the funds that have been budgeted are appropriately spent.

The process of financial supervision at MA Al Mua'wanah begins with setting standards, implementing 
leadership, financial supervisors identifying existing irregularities, and finally finding solutions to abnormalities that have been found.

Supervision activities compare activities between implementation and what is planned. Therefore there must be comparisons and comparisons. In implementing financial supervision, what is meant by contrast is the standard or benchmark for the financial supervisor to carry out the financial supervision process.

The supervisory standard or benchmark used by the financial supervisor at MA Al Mu'wanah is the RAPBM.

After the financial supervisors determine the standards, the next step is that the financial supervisors, both internal and external supervisors, carry out the supervisory process. Numerous studies have demonstrated that supervisors engage in behaviors to support newcomers in terms of information, feedback, and knowledge that encourage their newcomers' performance (Dufour, Andiappan, \& Banoun, 2021).

The supervision process is carried out by examining the implementation with the plan or comparing the financial statements with the RAPBM. The performance of internal financial supervision is carried out by the head of the Madrasah, which is carried out once a month. Due to the potential challenges of obtaining high fidelity image quality from the site's procedures and the inability to provide tactile feedback, supervisors felt virtual surveillance would be best suited for advanced learners during non-high-risk procedures (Sharma, Panigrahi, Sarmah, \& Dubey, 2019).

External supervision carried out by the Government is carried out once every semester, and maintenance carried out by the chairman of the Foundation is carried out once a year. Conducting inspection activities is not always according to plan; there is a possibility that in the middle of the year, one of the financings is not by the program.
Through this monitoring process, the financial supervisors, both internal and external supervisors, can determine what is not by the plan.

After discovering deviations or discrepancies between the plan and implementation, the financial supervisor must find a solution or resolution to the problem.

The head of the Madrasa as a financial supervisor is responsible for making decisions for solving existing problems. The head of the Madrasa alone does not do decision-making related to finance, but the director of the Madrasa first discusses with the head of the Foundation.

The financial supervision process at MA Al Mua'wanah is the supervisory process (Fattah 2004); namely, the financial supervision process begins with setting standards. The financial supervision standard set by the financial supervisor at MA Al Mua'wanah is the RAPBM.

The next stage is the implementation of supervision; control can also be interpreted as an activity to compare what happened with the standards set; internal parties and external parties carry out financial leadership.

When carrying out the supervision of the financial supervisor to identify whether there are deviations or not, after placing the existence of variations, the financial supervisor must be able to find solutions or make decisions regarding the deviations that have been found.

Every public institution, especially an institution that uses public funds such as schools, must carry out financial accountability, and MA Al Mua'wanah, which carries out financial responsibility through accountability reports.

The accountability report serves as a form of accountability for an institution. Through the accountability report, interested parties can determine that MA Al Mua'wanah has used madrasa money responsibly and according to plan. 
The financial accountability process carried out by MA Al Mua'wanah begins with the preparation of financial reports addressed to the Government, in this case, is the Ministry of Religion, and to the Al Mua'wanah Majalaya Foundation; the next step after the preparation of the accountability report is the approval or ratification of the accountability report by the chairman of the Foundation.

Every month the treasurer compiles a financial report addressed to the head of the Madrasa so that the head of the Madrasa can find out how much revenue the Madrasa gets in one month and how much expenditure is spent by the Madrasa in one month.

Every quarter the head of the Madrasa and the treasurer of the Madrasa prepare an accountability report to use BOS funds addressed to the Government. This accountability report is used to state that the procedures have used the BOS funds received by the Madrasa for their use. Meanwhile, financial accountability reports for foundations are prepared once a year.

The accountability report given to the Al Mua'wanah Majalaya Foundation is prepared at the end of each academic year. Examination related to activities, work programs, and financial conditions at MA Al Mua'wanah reported by the Madrasa whether it was by what was planned at the beginning of the school year or not.

The accountability report can be valid when the chairman of the Foundation signs the accountability report. Financial accountability is a form of public accountability from an institution, especially for public funding sources.

MA Al Mua'wanah carries out a financial accountability process that begins with preparing a financial accountability report and ratifying an accountability report.

The accountability report prepared by the head of the Madrasa and the treasurer of the Madrasa contains an accountability report on the receipt of funds and the general use of funds for one fiscal year. This is by the opinion (Nafisah \& Widiyanto, 2017) regarding financial accountability, where financial responsibility concerns the accountability process for receiving funds and using school funds.

The implementation of financial accountability at MA Al Mua'wanah is associated with (Nafisah \& Widiyanto, 2017) about the financial accounting process. There is a difference, namely in the ratification of the accountability report.

The accountability report that has been prepared by the Madrasa and submitted to the Foundation will later be ratified by the chairman of the Foundation.

The ratification of the financial accountability report needs to be done because the ratified accountability report can be used as concrete evidence that Madrasa has implemented accountable management of education financing.

B. Research Findings at MA Al Jawahir Soreang, Bandung Regency

\section{Education Financing Planning}

Planning is a process of determining goals or targets to be achieved in determining the roads and resources needed to achieve goals as efficiently and effectively as possible. MA Al Jawahir Soreang conducts financial planning involving parents, school committees, and village communities. Before the Madrasah financial planning is done, the Foundation provides a letter of notification to the parents of students to be present in the Madrasah financial budget planning. There are several things that MA Al Jawahir Soreang does in carrying out education financing planning, including:

1) Preparation of the Madrasah revenue and expenditure budget plan In preparing the Madrasah budget plan, MA Al Jawahir plans the needs for activities that the Madrasa will carry out within the following year. There are at least nine sectors, including 1). salary, 2). office stationery, 3). learning activities, 4). student activities, 5). facilities and infrastructure, 6). I am 
shopping for goods and consumables, 7). the service fee, 8). transportation, meetings, and 9). other unexpected expenses. This budget plan contains a draft revenue and expenditure budget used as a guide in carrying out Madrasah activities next year. The budget for MA Al Jawahir Soreang functions as a tool for estimating the cost requirements needed and details of expenses and their activities. A budget contains estimated income from various types of donations and expenditures for diverse Madrasah needs. Financing planning to improve the quality of learning is allocated to the standard process. The funding plan for the legal process amounts to $9,192,000$ obtained from $9,192,000$ BOS funds directed at improving the quality of learning tools at MA Al Jawahir Soreang. Some of the plans above show that MA Al Jawahir Soreang directs financing activities for improving the quality of Madrasah, both academic and nonacademic, physical and nonphysical, to create quality educational institutions. MA Al Jawahir Soreang also focuses its budget on maintaining the quality of the library by posting the development of the library, because the library is the primary source in improving the quality of Madrasah and MA Al Jawahir Soreang has a satisfactory achievement, namely the first winner at the national level in library management. The final results of the annual meeting are in the form of expenses and income or receipts, which are then compiled into a RAPBM. Sources of income or receipts of funds received by MA Al Jawahir Soreang are routine receipts and non-routine receipts. This income usually comes from students, foundations, the Government, and voluntary funds from the community, which is then used to finance expenses for Madrasah activities by the established program. MA Al Jawahir
Soreang also applies transparent management involving all school members. The data and information proposed by the Madrasah are then offered to parents and the surrounding community, especially from donors.

2) Development of Madrasah Revenue and Expenditure Budget Plan In the planning process, the objectives or targets to be achieved have been determined. The following procedure develops the RAPBM at MA Al Jawahir Soreang by forming a working group consisting of Madrasahs and their deputy head of Madrasah, treasurer, and administrative staff in year-end or early-year meetings. This meeting plans what needs a budget based on a proposal given by the teacher through the deputy head of the Madrasah, including curriculum, students, facilities and infrastructure, and others. This working group has the task of, among others, calculating the costs that must be incurred based on the estimated needs by needs of the Madrasah. Then grouped and calculated according to the needs of the Madrasah. Estimates of cost requirements carried out by the working group are then selected for allocations that are estimated to be very urgent and cannot be reduced, while those that are deemed not to interfere with the smooth running of educational activities, especially the teaching and learning process. Then it can be done with priority scale guidelines. This activity is carried out at the beginning of the year or the end of the year. In addition, the preparation of program plans, activities, and financing of MA Al Jawahir Soreang for strategic issues in the field of education, as well as analyzing the external and internal environment contained in the SWOT analysis, namely an analysis that includes strengths, weaknesses, opportunities, and threats. By examining the failings, it can be seen which components are 
considered inhibiting factors for improving performance, and a performance improvement strategy is needed to cover these weaknesses. Strength analysis is a potential that can be improved for institutional development. Opportunities are data from external factors that support the implementation of activities that must be empowered. At the same time, threats are external factors that threaten the organization's existence, which must be minimized. According to research in the field, the results of the work meeting resulted in priority scale activities for the preparation of program plans and actions that lead to improving the quality of madrasas based on eight school quality standards because the determination of the priority scale analyzes the problems faced by the units supported by accurate data and information, along with efforts to solve the problem.MA Al Jawahir Soreang carries out the planning of activity and the allocation of appropriate and fair costs based on program priorities and activities that have been set in the work plan with each deputy head of the Madrasah in each education sector having made a program plan of activities and then submitted to the authority of the Madrasa for approval.

\section{Implementation of Education Financing}

The implementation of financing management at MA Al Jawahir Soreang carried out various negotiations regarding the results of the RAPBM. Usually, the program that requires additional costs is adjusted to the number of fees to be incurred.

In practice, the treasurer serves as a regulator if there is money coming in either from students or the Government or foundations. Regulate how financial receipts are correctly used. As well as the task of managing expenditures to be allocated to each field of education by those listed in the activity program in the RAPBM.
The implementation of financing management at MA Al Jawahir Soreang has two types of revenue and expenditure activities.

1) Reception

Education financing, as stated in the Regulation of the Minister of Religion No. 90 of 2013 concerning the implementation of Madrasah education, says that Madrasah financing comes from the Government, local governments, Madrasah administrators, the community, and sources from anywhere that are legal and do not violate applicable laws.

The financing is used as investment, operating, and personal costs that lead to quality educational institutions. Fees received at MA Al Jawahir Soreang come from routine and non-routine income. Regular income comes from registration fees, 1-year activity fees, shodaqoh, every month and donations from students' parents, usually carried out at the beginning of the year in the form of infaq maintenance and development of infrastructure and uniforms, activity money for one year, and others used for finance all educational activities. Meanwhile, non-routine income comes from government assistance such as BOS and business entities owned by foundations and voluntary. Voluntary donations are donations received by Madrasas from individuals and the community.

These voluntary donations are grants, land waqf, material donations, and building donations. School financial receipts from funding sources need to be recorded based on management procedures that are in line with agreed provisions, both in the form of theoretical concepts and government regulations.

The school's financial income comes from the Government, special receipts for education such as foreign aid or loans intended for education, tuition fees, and 
voluntary donations from parents and the community. The financial acceptance process is quite long through approval, among others, from the financial supervisor, treasurer, assistant director of finance through receipts of official reports, usually acceptance comes from students. Usually, the money that has been received is directly deposited in the bank for security.

2) Expenses

The implementation of expenditures at Madrasah Aliyah Al Jawahir Soreang includes routine expenses and non-routine expenses. Typical fees include recurring payments that are issued every month. Non-routine expenses include costs that are not given every month. This non-routine expenditure is carried out if there is a sudden need or need that is carried out every year and also requires that was previously planned in the RAPBM.

The main financing programs carried out by MA Al Jawahir Soreang are provided with posts, including:

a. Post Curriculum

Two main sectors pay attention to funding in the curriculum sector, namely developing the quality of human resources through detailed activities and improvement of supporting learning activities such as learning tools.

b. Student post

Five main sectors receive attention from student funding: Student admissions, skills, selfdevelopment, talents, interests, and arts.

c. Post suggestions and infrastructure

Four main sectors pay attention to funding in the field of facilities and infrastructure, namely: 1) Procurement of infrastructure to support teaching and learning activities such as the construction of buildings, dormitories, equipment, and materials 2) Maintenance can be carried out periodically and incidentally 3 ) Inventory 4) Utilization of facilities and infrastructure.

d. Post community activities

Post community activities under the waka of public relations, funding for public relations aims to carry out connections with the community optimally, several public relations activities that require a funding budget include: 1) Holding a student guardian meeting 2) Deliberation on learning activities 3) Home visit 4) Letter 5) School Publicity 6) Calendar.

e. Library post

Post library under the control of the head of librarianship, the library becomes the main post because the library is an essential tool in improving the quality of education. A good funding process and systematic management-led MA Al Jawahir Soreang to become the first champion of the national library.

Efforts to improve the quality of education, especially in MA Al Jawahir Soreang, are an essential part of improving the quality of existing resources in madrasas to be developed towards the best quality, which refers to eight educational quality standards. MA Al Jawahir Soreang manages the sources of funds according to management procedures that are in line with the agreed accuracy, both in the form of theoretical concepts and government regulations.

Based on the results of the field results, the financial acceptance procedure of the MA Al Jawahir Soreang was carried out based on practices that did not deviate from the instructions for use and expenditure that had been agreed in the RAPBM; this was in (Nafisah \& Widiyanto, 2017) that to make school financial planning effective, The 
principal responsible for implementing it must be the school principal. The principal must be able to develop several dimensions of administrative making. The ability to translate educational programs into financial equivalents is critical to budgeting. Making a budget is not a routine or mechanical job. It involves consideration of the primary aims of education and programs.

Based on this perspective, school financial planning must pave the way for developing and explaining concepts about the desired educational goals and designing ways to achieve them. Financial management at MA Al Jawahir Soreang is managed directly by the treasurer. Meanwhile, the Head of Madrasah MA Al Jawahir Soreang is only in charge of managing educational activities at the Madrasa.

The Head of Madrasah is in charge of implementing how to improve the quality of education, namely by coordinating activities to enhance the quality of education through financing that the assistant director of finance has regulated.

\section{Education Financing Supervision}

The implementation of activities that use relatively limited sources of funds requires supervision and control aimed at, among other things, so that all system components move effectively and efficiently. The task was developed to utilize unlabeled data better and extended to labeled data to enrich surveillance signals. With the proposed scheme in multi-task mode, our method achieves better performance than models with the same network architecture, which gets the goal of helping the model to play maximum effect (Kang, Liu, Liu, Zhou, \& Ye, 2021).

Financing supervision at $\mathrm{MA} \mathrm{Al}$ Jawahir Soreang is carried out by the head of the Madrasah and the deputy head of the Madrasah by checking at the beginning of each month and the end of the month to the treasurer. The supervision of financing is divided into two if Madrasas and foundations supervise funds from the community if funds from the Government are reported to the Government by government regulations.

The examination of the financial income of Madrasahs at MA Al Jawahir Soreang was carried out from two directions, namely from internal Madrasahs carried out by the Madrasah head and from external Madrasas carried out by foundations, school committees, and village communities.

This examination assesses the possible sources of funds which usually come from parents and the Government, community assistance, voluntary donations from students' parents, and school entrepreneurial activities.

Madrasa financial management in the implementation of the Madrasah system is too complicated. If there is a financial need for sudden activity programs from each financial sector, disbursing funds goes through two stages so that the process of funding takes a long time when needed. In addition, the absence of accountability to the Madrasah committee results in its responsibility only to the Madrasah head and treasurer, who knows the finances.

MA Al Jawahir Soreang is compiling a monitoring program through $\mathrm{E}$ Budgeting, which was actively carried out in 2018 and is now being started by the treasurer by recording all income and expenses in the excel program instead of on a book, by monitoring once a month the minutes of inspection or auditing so that they can anyone can see, because MA Al Jawahir Soreang, which is a sizeable private Madrasah, needs transparency in Madrasah financing because it is prone to budget abuse.

Monitoring with E-Budgeting is needed to produce information about the implementation of various operational activities that are currently 
taking place. The data were obtained in multiple ways: by reporting, interview results, distribution, questionnaires, and direct observation by supervisors in the field. Observations are carried out by monitoring or monitoring activities that are being and have been carried out.

The monitoring mechanisms include:

a. Carry out monitoring on work units or implementing activities to collect data and information.

b. Analyze data and information on the implementation of activities as evaluation material.

c. Evaluate the results of the performance of activities as report material.

Monitoring does not only receive reports from implementers

activities, but also analyze the suitability of actions and plans, both from the physical and non-physical aspects in the field. For example, monitoring the conformity of the specifications of goods, tools, or another physical between the accountability reports and the goods before they are given to users by the procurement committee and the recipient of the goods.

The control system carried out by EBudgeting is carried out

periodically to avoid deviations from the predetermined plan. Periodic internal control to prevent variations early or not too long. Because the deviation is too far, it isn't easy to control.

About financing management, control is also directed to evaluate the stages of using state finances, starting from the planning process to control. (Supriadi, 2006) detailed the meaning contained in accountability, namely," Suitable or by the expected role; Explaining and considering others about actions and decisions taken, and a performance that fits and calls for consideration from others."

Based on this definition, it can be concluded that the aspects that

contained in accountability, among others: satisfaction from other parties; control model and size criteria. The pleasure from the other party can occur if, according to the fact, it can fulfill what has been determined precisely or by the desired criteria and is reflected in control carried out by the other party. Thus, accountability is a state of performance of cost management officers who can work and provide work results by predetermined criteria, satisfying interested parties.

Based on this, (Supriadi 2006) details the steps to determine accountability as follows:

a. Develop performance criteria for each program

b. Set up free checks to measure performance

c.Prepare reports to the public on measurement results.

In line with the above opinion, accountability is an increase the attitude of the manager's responsibility includes:

a. Efficient and effective use of resources.

b. Conformity between goals, results, and functional activities and results with morals, ethics, and community values.

c. Concern about continuous quality improvement by the demands of interested parties.

Thus, it can be concluded that this realization has gone too far and is difficult to control. About financing management, control is also directed at evaluating the stages of using state finances, starting from the planning process to maintaining; accountability in cost management is reflected in the existence of bookkeeping, inspection, and reporting. The control system carried out by MA Al Jawahir Soreang is carried out periodically to avoid deviations from the predetermined plan.

Periodic internal control to avoid deviations early or not too long. Because the variation is too far, it isn't easy to control. Regarding financing management, power is also directed at evaluating the stages of state finances, 
starting from the planning process to manage.

\section{CONCLUSION}

Management of education financing to improve the quality of learning in Madrasah Aliyah is still not optimal. It is proven that the quality of learning has met the standard of the learning process and seen from the teaching staff's readiness to prepare the learning process by the format of the national education quality standard. However, let's look closely at the occurrence of learning interactions between educators and students. Some educators need to increase their ability to stimulate stimulus responses from students in encouraging motivation, interest, and serious attention in developing and mastering learning materials.

\section{REFERENCES}

Agatha, Frastika. (2019). Layanan Konseling Islami Dalam Menanggulangi Stres Belajar Siswa Kelas Xi Sma Negeri 1 Selesai Tahun Pelajaran 2018/2019. Universitas Islam Negeri Sumatera Utara.Google Scholar

Barnawi \& Arifin, M. (2012). Manajemen Sarana Dan Prasarana Sekolah. Jogjakarta: Ar-Ruzz Media. Google Scholar

Dufour, Lucas, Andiappan, Meena, \& Banoun, Arnaud. (2021). Support Or Evaluate?: The Multifaceted Role Of Supervisors During The Newcomer Socialization Process. European Management Journal, (August).

Https://Doi.Org/10.1016/J.Emj.2021.08. 006 Google Scholar

Fattah, H. Nanang. (2004). Konsep Manajemen Berbasis Sekolah (Mbs) Dan Dewan Sekolah. Pustaka Bani Quraisi. Google Scholar

Febriyanti, Citra Rizky. (2020). Pengaruh Manajemen Pembiayaan Terhadap Mutu Lulusan Madrasah: Penelitian Di Madrasah Aliyah Al Jawami Cileunyi Kabupaten Bandung. Uin Sunan Gunung
Djati Bandung. Google Scholar

Indonesia, Presiden Republik. (2003). Undang-Undang Republik Indonesia Nomor 20 Tahun 2003 Tentang Sistem Pendidikan Nasional. Jakarta. Google Scholar

Kahfi, Inal. (2019). Tqm Dan Quality Improvement. Bandung: Stai Yamisa Soreang. Google Scholar

Kang, Liangyi, Liu, Jie, Liu, Lingqiao, Zhou, Zhiyang, \& Ye, Dan. (2021). SemiSupervised Emotion Recognition In Textual Conversation Via A ContextAugmented Auxiliary Training Task. 58(August). Google Scholar

Lamothe, Josianne, Geoffrion, Steve, Couvrette, Amélie, \& Guay, Stéphane. (2021). Supervisor Support And Emotional Labor In The Context Of Client Aggression. Children And Youth Services Review, 127(June). Https://Doi.Org/10.1016/J.Childyouth.20 21.106105 Google Scholar

Muqit, Abd, \& Listiana, Heni. (2021). Manajemen Pembiayaan Dalam Peningkatan Mutu Pendidikan. Journal Multicultural Of Islamic Education, 4(2), 81-93. Google Scholar

Nafisah, Durotun, \& Widiyanto, Widiyanto. (2017). Manajemen Pembiayaan Pendidikan Di Madrasah Aliyah. Economic Education Analysis Journal, 6(3), 788-797. Google Scholar

Saway, M. Hijrah M., \& Hidayat, Ara. (2019). Implementasi Manajemen Pembiayaan Dalam Pemeliharaan Sarana Dan Prasarana Pembelajaran Madrasah Aliyah Di Kabupaten Bandung. Manazhim, 1(2), 130-141. Google Scholar

Sharma, Hari Bhakta, Panigrahi, Sagarika, Sarmah, Ajit K., \& Dubey, Brajesh K. (2019). Journal P Re Of. Science Of The Total Environment, 135907. Https://Doi.Org/10.1016/J.Aca.2021.338 884 Google Scholar 
Shunhaji, Akhmad, Abd Muid, N., \& Desniati, Pipin. (2020). Manajemen Pembiayaan Pendidikan Pondok Pesantren Darul Muttaqien Parung Bogor. Andragogi: Jurnal Pendidikan Islam Dan Manajemen Pendidikan Islam, 2(1), 18-39. Google Scholar

Siti, Julaeha. (2021). Kinerja Manajerial Kepala Sekolah Dalam Peningkatan Mutu Pendidikan Di Smk Al Furqon Bantarkawung Kabupaten Brebes. Iain Purwokerto. Google Scholar

Sudrajat, Asep Rahman. (2019). Manajemen Pembiayaan Pendidikan Madrasah
Tsanawiyah Satu Atap. Manazhim, 1(2), 166-182. Google Scholar

Sugandi, Moh. (2019). Manajemen Pembiayaan Pendidikan Pondok Pesantren: Penelitian Pembiayaan Pada Pondok Pesantren Miftahulhuda AlMusri'dan Pesantren Al-Huda Di Kabupaten Cianjur, Jawa Barat. Uin Sunan Gunung Djati Bandung. Google Scholar

Supriadi, Dedi. (2006). Satuan Biaya Pendidikan Dasar Dan Menengah. Google Scholar

\section{Copyright holder:}

Inal Kahfi (2021)

First publication right:

Journal of Social Science

This article is licensed under: 